2015

\title{
Discussing Advocacy Skills in Traditional Doctrinal Courses
}

Stephen A. Newman

New York Law School

Follow this and additional works at: http://digitalcommons.nyls.edu/fac_articles_chapters

Part of the Family Law Commons, and the Legal Education Commons

\section{Recommended Citation}

65 Journal of Legal Education 207-228 (2015).

This Article is brought to you for free and open access by the Faculty Scholarship at DigitalCommons@NYLS. It has been accepted for inclusion in Articles \& Chapters by an authorized administrator of DigitalCommons@NYLS. 


\title{
Discussing Advocacy Skills in Traditional Doctrinal Courses
}

\author{
Stephen A. Newman
}

Can teaching students in doctrinal courses, using traditional case-oriented materials, convey some of the skills lawyers need to practice law effectively? While the recent interest in and debate over training practice-ready lawyers makes this a timely question, my thinking about this harks back to the midI990s, when Harry Wellington, then dean of New York Law School, ${ }^{1}$ suggested that faculty members consider teaching law from the lawyer's perspective rather than from the perspective of either the judge or the legal scholar. ${ }^{2}$ Clinical courses had done this from the outset, of course, but traditional doctrinal courses commonly aimed to teach legal doctrines by studying judicial opinions in a scholarly way. Because practicing law requires the skill of case analysis and the application of legal concepts, it is important to study the opinions of judges in an academically rigorous way.

In taking up Dean Wellington's challenge, my goal in teaching my introductory course in family law was to incorporate a variety of ideas about practical legal skills in class discussions about judicial opinions. This would not convert the course into a skills course. But regular additions to class discussion of such matters as gathering evidence, using narrative techniques in presenting evidence, narrowing legal claims, naming parties, counseling clients, and dealing with experts could help students see the connections between doctrinal law and practice, stimulate thinking about how lawyers go about making a persuasive case on behalf of their clients, and reinforce the students' learning in skills and experiential learning courses. I offer some examples from my own course, with the expectation that instructors of other doctrinal courses will have their own ideas for incorporating into class discussions these ways of thinking about the lawyer's job.

Stephen A. Newman is Professor of Law Emeritus, New York Law School

I. Adam Liptak, Harry H. Wellington, Dean at Yale and a Labor Law Expert, Dies at 84, N.Y. Times, Aug. 9, 20II, http://www.nytimes.com/20II/o8/io/nyregion/harry-h-wellington-formerdean-of-yale-law-school-dies-at-84.html.

2. See, e.g., Harry H. Wellington, Challenges to Legal Education: The "Tiwo Cultures" Phenomenon, $37 \mathrm{~J}$. Legal Educ. 327 (1987). 


\section{Finding and Presenting Evidence}

You might not know it from examining most casebooks, but practicing lawyers must give serious, sustained attention to gathering evidence in every case. They must search it out, discuss it with their clients, and present it to judges in motions, at trial, and on appeal. So it seems appropriate to draw attention to this crucial aspect of the lawyer's work during class discussions of traditional cases.

Traditional appellate opinions give readers the facts, and so elide the effort lawyers make to find those facts. Often, though, appellate judges will remand a case for further proceedings, and this gives the instructor an opportunity to open up for discussion the fact-gathering necessitated by the new hearing in the case. The family law classic Matter of Baby M.3 provides an example. In the New Jersey Supreme Court, Mary Beth Whitehead, who contracted with William Stern to be a "surrogate mother" for his child, sought custody of the child or, alternatively, visitation with the child. ${ }^{4}$ The New Jersey Supreme Court explained its negative feeling about surrogacy contracts, ${ }^{5}$ and the case is an excellent vehicle for discussing problems raised by new reproductive technologies. But after the court ruled the surrogacy contract against public policy and unenforceable, and affirmed the determination that the Sterns should be awarded custody, it remanded the matter for a hearing on Ms. Whitehead's visitation rights. ${ }^{6}$

The remand presents an opportunity to ask students to work out the narrative line of the Sterns' argument that, in the best interests of the child, Ms. Whitehead's contact with the child should be limited and even delayed for years, and Whitehead's contrary argument that visitation should be generous and begin immediately. The students can also be asked to consider what evidence might support Whitehead in her quest for visitation, and whom she might call to testify. The Sterns' argument that visitation would create an unstable and upsetting situation for the child might be countered by evidence derived from the experience of visitation during the pendency of the litigation. Baby M.'s situation might be analogized to the circumstances in numerous divorce cases, where a parent with custody has a new spouse, yet must respect the visitation rights of the other parent. The case on remand is reported,7 enabling the professor to inform the students about the actual evidence, arguments, and outcome in the remanded case.

3. $\quad 537$ A.2d I227 (N.J. I988).

4. Id. at $1234-35$.

5. Id. at $1240-47$.

6. Id. at I234-35.

7. 542 A. 2 d 52 (N.J. Super. Ct. I988). Another remanded custody matter is Bennett v. Marrow, 399 N.Y.S.2d 697 (Sup. Ct. 1977), on remand from Bennett v. Jeffreys, 40 N.Y.2d 543 (1976). This case highlights the testimony of an expert in psychology from Yale University that aligns well with the theories propounded in Joseph GoldsteIn, ET AL., Beyond the Best INTERESTS OF THE CHILD (I973). 
A U.S. Supreme Court case, J.D.B. v. North Carolina, gives law students a chance to think about fact-gathering in a quasi-criminal case involving a juvenile's confession to unlawful conduct. ${ }^{8}$ School officials escorted a i3-yearold boy to a room in the school for questioning by the police about burglaries committed in the neighborhood. 9 The youth was questioned for 30 minutes and released upon the conclusion of the school day, after he incriminated himself by his answers. ${ }^{\text {IO }}$ When a juvenile delinquency petition was filed against him, his lawyer argued that he had been "in custody" and therefore should have been given Miranda warnings. "The state courts found he was not "in custody" and so not entitled to the warnings. ${ }^{\mathrm{I} 2}$ On appeal to the U.S. Supreme Court, the issue decided was the narrow one of whether courts must take into account the age of the minor in determining whether he was "in custody" for Miranda purposes. ${ }^{13}$ The Supreme Court held that the age of the child was a mandatory factor in the analysis. ${ }^{14}$ It declared that the issue had to be resolved by a determination of "whether given the circumstances, a reasonable person [would] have felt he or she was . . . at liberty to terminate the interrogation and leave." 55 The matter was remanded for further proceedings. ${ }^{16}$

Rather than give students the facts as recited by the court, I give them the court's discussion of the legal standard for determining whether someone is in custody, and ask my students to grapple with the practical effect of the court's ruling on the continuing litigation. What facts do they need to gather in the effort to argue that the boy was "in custody"? In a short time, students can usually come up with a series of questions about the facts of the interrogation that the boy's lawyer must have answered (e.g., who was in the room, how many of those present were police officers, whether the officers were armed, whether the door was open or closed, locked or unlocked, blocked by officers or freely accessible, whether the boy was handcuffed or otherwise physically restrained, what was said to the boy about his obligation to answer questions and to remain in the room, how long the interrogation lasted, how it concluded, whether the boy ever asked to leave). This brief class discussion helps convey the idea that evidence gathering and asking the right questions to obtain the evidence are essential tasks for the lawyer, and often the key to winning or losing the case.

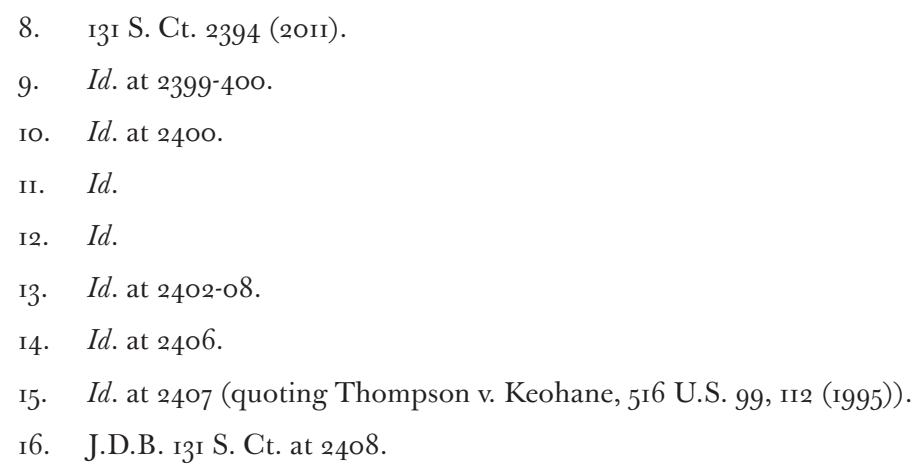


Another example is Marvin v. Marvin, the landmark case from the California Supreme Court that recognized the right of an unmarried co-habitant, plaintiff Michelle Triola Marvin, to make claims for property division and support against her movie-star lover, Lee Marvin. ${ }^{17}$ The claim is popularly dubbed "palimony." 18 The case came to the state's high court on a motion addressed to the sufficiency of the pleadings, ${ }^{19}$ and Michelle's lawyer won a great victory in just keeping her claim alive. She was allowed to rely upon contract, implied contract, and equitable theories to recover on her claims, including recovery based on proof of her "reasonable expectations" upon termination of the relationship. ${ }^{20}$

To highlight the work of the practicing lawyer, I ask students to anticipate the case on remand. If Michelle could not prove the existence of an express contract (which she, in fact, couldn't), how might she argue about her reasonable expectations? A brief discussion might elicit various ideas about each lawyer's argument and search for supporting evidence. Michelle's lawyer would want to tell a story focused on the sacrifice of her singing career, and her significant contributions as a homemaker and companion to Lee over the years of their living together. Students could then consider Lee's strategy in response. Lee would want to minimize Michelle's supposed sacrifice of career by showing she was just another struggling entertainer with limited prospects and a career going nowhere. Her contributions to Lee's home could be minimized by pointing out the kind of domestic help Lee hired to do the housekeeping, cooking, cleaning, maintenance of grounds, etc. Lee could produce evidence of the benefits Michelle had already reaped from the relationship-e.g., gifts of furs, jewelry, clothing, and other goodies of the high life that movie stars enjoy in our society-and argue that she had been generously rewarded for whatever contributions she made. The case on remand is reported, enabling the instructor to tell the class how it all came out. Michelle won the battle in the California Supreme Court but lost the war on remand. ${ }^{21}$ She was awarded no money at all in the final round of adjudication of her claim. ${ }^{22}$ The benefits she reaped were substantial, the remand court found, and overwhelmed any contributions and sacrifices Michelle made. ${ }^{23}$ Only her lawyer became rich

17. 557 P.2d Io6 (Cal. 1976).

I8. See Lina Guillen, Palimony, DivorceNet, http://www.divorcenet.com/states/nationwide/ palimony (last visited April 22, 2015).

I9. Marvin v. Marvin, 557 P.2d at IIO-II.

20. Id. at $116-23$.

2I. Marvin v. Marvin, i76 Cal. Rptr. 555 (Ct. App. 198I).

22. Id. at $55^{8-59}$.

23. The court found Lee contributed over \$72,900 for Michelle's sole benefit and some \$221,400 for their joint living expenses, plus substantial gifts for Michelle, in the five years they lived together. $I d$. at 557 . 
and famous from the case (but he, too, lost the war, later serving a prison term for income tax evasion)..$^{24}$

As a final example, I use an oft-cited custody case not from the West Reporters, but from the Bible. Some judges write in their opinions that they wish that they had the wisdom of Solomon, or declare that a case is so close as to require Solomonic judgment. ${ }^{25}$ They refer, of course, to the venerable custody case reported in the Book of Kings. One version goes like this:

And the wise king judged the two women before him. Each had a child newly born, but one child had died. Each woman claimed the living child as her own. And the king said, "Fetch me a sword."

And they brought him a sword. And the king said, "Divide the living child in two, and give half to the one, and half to the other." Then spoke the woman whose the living child was, for her heart yearned upon her son, and she said, "Oh, my lord, give her the living child and in no wise slay it." But the other said, "It shall be neither mine nor thine; divide it."

Then the king answered and said, "Give her the living child, and in no wise slay it; she is the mother of the child." And all Israel heard of the judgment which the king had judged; and they feared the king; for they saw that the wisdom of God was in him, to do justice. ${ }^{26}$

When judges seek Solomonic wisdom, it is usually because the case is a close one, with the evidence very evenly split between the parties. But I suggest to the class that the biblical story is not about a close case. It is about a dispute resolved by overwhelming evidence favoring one party over the other. Solomon played two roles in this story, in terms of our modern legal systemthat of judge (the decision-maker) and that of lawyer (the evidence gatherer and presenter). It was Solomon's brilliant evidentiary presentation that won the day. Solomon's ingenious demonstration left no doubt about who was the true mother of the child. The lawyer's job-to come forward with evidence, ideally evidence so persuasive that only one judgment seems possible-was dispatched with such effect that no one could question the judgment that inexorably

24. See his obituary for the fascinating story Patrick Healy, Marvin Mitchelson, Father of Palimony, is Dead at 76, N.Y. Times, Sept. 20, 2004, http://www.nytimes.com/2004/o9/20/ obituaries/2oMitchelson.html.

25. See, e.g., Byron v. Davis, 950 N.Y.S.2d 679, 680 (Sup. Ct. 2012) ("Lacking the wisdom of Solomon to decide this difficult question for two members of the clergy . . .."); Ferguson v. Lewis, 3I So.3d. 5 (Miss. Ct. App. 2009) ("It is often said that chancellors must have the wisdom of Solomon in domestic cases. It may also be said that chancellors must have much more wisdom than Solomon when dealing with teenagers."). For an interesting discussion of how the King Solomon story portrays the image of the ideal judge, see Linda L. Berger, How Embedded Knowledge Structures Affect fudicial Decision Making: A Rhetorical Analysis of Metaphor, Narrative, and Imagination in Child Custody Disputes, I8 S. CaL. InTERdisc. L.J. 259 (2009).

26. I Kings 3:I6-28. 
followed. Solomon's work as lawyer made the difference, and made his work as judge easy. ${ }^{27}$

\section{Storytelling}

"Law lives in narrative" in the words of Professors Anthony Amsterdam and Jerome Bruner, in their extensive study Minding the Law. ${ }^{28}$ "Clients tell stories to lawyers, who must figure out what to make of what they hear. As clients and lawyers talk, the client's story gets recast...If circumstances warrant the lawyers retell their clients' stories in the form of pleas and arguments to judges and testimony to juries... Next, judges and jurors retell the stories to themselves or to each other in the form of instructions, deliberations, a verdict, a set of findings, or an opinion. And then it is the turn of journalists, commentators, and critics. This endless telling and retelling, casting and recasting is essential to the conduct of the law." 29

Legal philosopher Ronald Dworkin proposed that the law itself is a continuing story, with each generation writing its own new chapter, while arguing over how the story should advance and who should be in position to do the writing. ${ }^{30}$

These matters can be brought down to concrete level in case discussions by recognizing not just the legal analysis, but the storytelling skills a lawyer must employ in presenting a case. Some ideas about doing this follow.

\section{Succinct Statement of the Case}

In many litigated cases, a judge first sees the case when a motion is made early in the litigation. And often enough (perhaps not yet having read any papers filed), the judge's first question is "What's this case about, counselor?" It is a valuable skill for lawyers to be ready to answer that question succinctly and well. Law professors might reconsider the common technique of asking students to recite the facts of a case, in some objective fashion, and instead ask students to answer the judge's question from the point of view of a lawyer representing one of the parties (e.g., the plaintiff, or the party appealing). This will sensitize students to the lawyer's difficulty in dealing with "the facts" of any case. Out of the welter of facts in any situation, what facts should be chosen in briefly telling the basic story of the case? Which facts need emphasis

27. Another Solomon story is similarly focused on finding irresistible evidence. The King and the Bees, Baldwin Project, http://www.mainlesson.com/display.php?author=baldwin\&bo ok=people\&story=bees (last visited April 22, 20I5). The king was challenged to distinguish between a wreath of flowers and an artist's masterful lifelike replica of the wreath. Id. Solomon could see no apparent difference between the two. Id. Then he asked that the window be thrown open. Id. A bee flew in and went directly to the true flowers. Id. Solomon had only to point to that wreath as nature's creation, and the other as the artist's. Id.

28. Anthony Amsterdam \& Jerome Bruner, Minding the Law (2000).

29. Id. at iıo.

3o. See Ronald Dworkin, Law's Empire (ig86). 
and which ones need to be minimized? How can the story be distilled down to a few essentials, in a way that is accurate and also persuasive?

Judicial opinions rarely recite the facts of the case before the court in a way that is brief and yet compelling. It is worth calling attention to the instances in which courts do demonstrate this skill. In Dunphy v. Gregor, for example, the court related the facts of an automobile accident with a striking use of a few well-chosen, telling details..$^{3^{\mathrm{T}}}$ The plaintiff, Eileen Dunphy, sought damages for emotional distress she suffered when she witnessed the death of her cohabitant and fiancé, who was hit by defendant's truck on a highway when changing a tire. Justice Alan B. Handler of the New Jersey Supreme Court described the incident this way:

Eileen Dunphy and Michael T. Burwell became engaged to marry in April Ig88 and began cohabitating two months later. The couple set a date of February 29, I992, for their wedding. On September 29, I990, the couple responded to a friend's telephone call for assistance in changing a tire on Route 80 in Mount Arlington. As Michael changed the left rear tire of the friend's car on the shoulder of the roadway, he was struck by a car driven by defendant, James Gregor. After being struck by the vehicle, his body was either dragged or propelled 240 feet. Eileen, who had been standing approximately five feet from Michael, witnessed the impact, and ran to him immediately. Realizing that he was still alive, she cleared pebbles and blood from his mouth to ease his breathing. She attempted to subdue his hands and feet as they thrashed about, all the while talking to him in an effort to comfort him. The following day, after a night-long vigil at Dover General Hospital, Eileen was told that Michael Burwell had died as a result of his injuries..$^{22}$

With a few carefully chosen details, the judge brings the scene vividly before our eyes. The account of the accident puts the plaintiff, Ms. Dunphy, in a very sympathetic light, and gives the reader a grasp on the profound emotional impact of the event on her. Add to the description a sentence defining the legal issue posed by the case - whether a non-family member should be permitted to sue in tort for emotional distress suffered when witnessing the fatal injury of a loved one-and you have an accurate, fact-based, and brief statement of the case. If it came from the plaintiff"s lawyer in reply to the "What's this case about?" question, it would succeed in subtly beginning the lawyer's effort to persuade the court to recognize his claim. 33

It is also worth noting when judicial opinions minimize key facts in order to bolster the opinion's persuasiveness. An example is Cruzan v. Director, Missouri Dept. of Health, in which parents sought to have their adult daughter, Nancy Cruzan, in a vegetative state with no hope of recovery, taken off life-support

$3^{\text {I. }} \quad 642$ A.2d 372 (N.J. Sup. Ct. I994).

32. Id. at 373 .

33. The lawyer succeeded; the court recognized Ms. Dunphy's tort claim, in broad terms that benefited all co-habitants in close, loving, intimate relationships. Id. at 379 . 
systems. ${ }^{34}$ The description of her condition could certainly influence the acceptability of the arguments for and against withdrawal. The case split the court 5-4 in favor of the state of Missouri, which had denied the parents the right to make this decision without clear and convincing evidence of what their daughter would have wanted done. ${ }^{35}$ How did the justices on each side in the case characterize Nancy's physical condition? In the majority's account, she is "incompetent," with "virtually no chance of recovering her cognitive faculties." $3^{6}$ In the dissent's account, Nancy is in a "twilight zone" between life and death, one that has lasted for six years and might continue for as many as thirty years, with a body that "twitches ... reflexively" and a brain that has "degenerated badly" with its cavities "filling with cerebro-spinal fluid." "All four of her limbs are severely contracted; her fingernails cut into her wrists. She is incontinent of bowel and bladder." ${ }^{8}$ This factual account strongly supports the dissenters' central idea that "Dying is personal. And it is profound. For many, the thought of an ignoble end, steeped in decay, is abhorrent. A quiet, proud death, bodily integrity intact, is a matter of extreme consequence." 39

Students sometimes find it difficult to imagine how a case story might differ from the one recounted in the judge's opinion. But before there was an opinion, there was a hotly contested case, with a legal question yet to be answered. Law student readers may easily be taken in by the judicial "rhetoric of inevitability" identified by Robert Ferguson as a regular occurrence in judicial opinions. ${ }^{4^{\circ}}$

One tactic for undermining the rhetoric of inevitability, and highlighting the lawyer's skill of telling a persuasive story, is to give the class a lower-court opinion to read that has (unbeknownst to them) been reversed on appeal. An example in family law is the case of Thomas S. v. Robin Y., in which two lesbian women arranged with a gay male friend to be a sperm donor for one of the women. ${ }^{41}$ After a successful artificial insemination, a female child named Ry was born. ${ }^{4^{2}}$ The women and Thomas S. agreed that he would not interfere with their parenting, and that he might interact with the child only if they later decided to invite him to do so. ${ }^{43}$ The invitation came, when the child was three. ${ }^{44}$ Thomas visited with the child over the next six years before asking

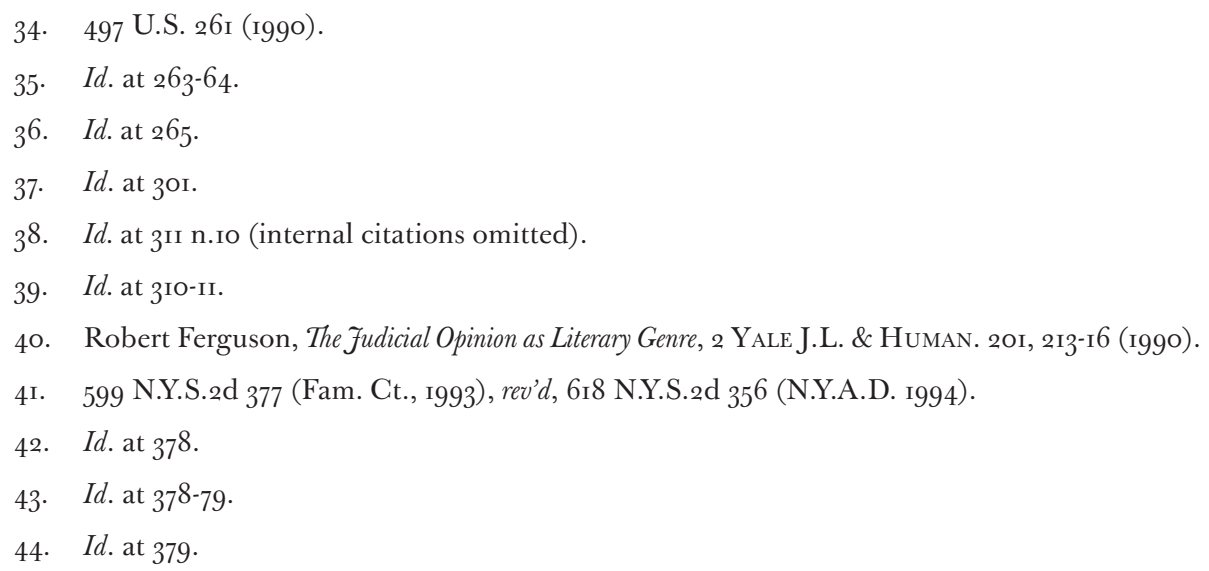


the women if he could take the child to visit his parents. ${ }^{45}$ They refused, and decided to terminate his visits. ${ }^{6}$ He sued to establish paternity and to resume visitation. ${ }^{47}$

The family court judge issued a reported opinion in favor of the women and told the story of the case from their perspective. $4^{8} \mathrm{I}$ give the students the family court opinion to read (not the Appellate Division opinion in the case), and ask them to consider how the lawyer for Thomas S. would relate the story of the case, assuming the truth of the facts related by the family court opinion. The lawyer for Thomas S. had a sound basis for insisting that the most significant facts favored his client. Students must consider which facts would be highlighted, and which facts minimized, in order to make Thomas's claim sound most persuasive. The key to his story are the years after the women invited him to form a relationship with the girl, and the constancy and strength of that relationship over the years. ${ }^{49}$ Students must resist the trial judge's attempt to place the focus of the story on the initial agreement that seemed to show Thomas's indifference to the child, and the first three years of the child's life, in which he had no part..$^{\circ}$ The appellate court did shift the focus to favor Thomas, finding the women should have been equitably estopped from denying Thomas a role in the child's life. ${ }^{5 t}$

The class may also consider questions about evidence to be gathered in making the claim. What might a lawyer look for, in trying to establish the existence of a close, loving relationship between Thomas and Ry? Students may rarely think about evidence outside the rules learned in a formal evidence course, but lawyers always think about sources of good evidence. The attorney for a man claiming parental status might try to find every email, Christmas card, photo, birthday greeting, thank-you note for gifts, etc., paying special attention to the tone of the contacts. Of great importance would be the search for affectionate phrases and terms of endearment employed by each of them, with the child's use of the terms like "I love you" and "daddy" being the equivalent of striking an evidentiary vein of gold.

\section{Lengthier Statement of the Facts}

Lawyers must also compose lengthier accounts of case facts for jury summations, and trial and appellate briefs. Appellate opinions do not readily

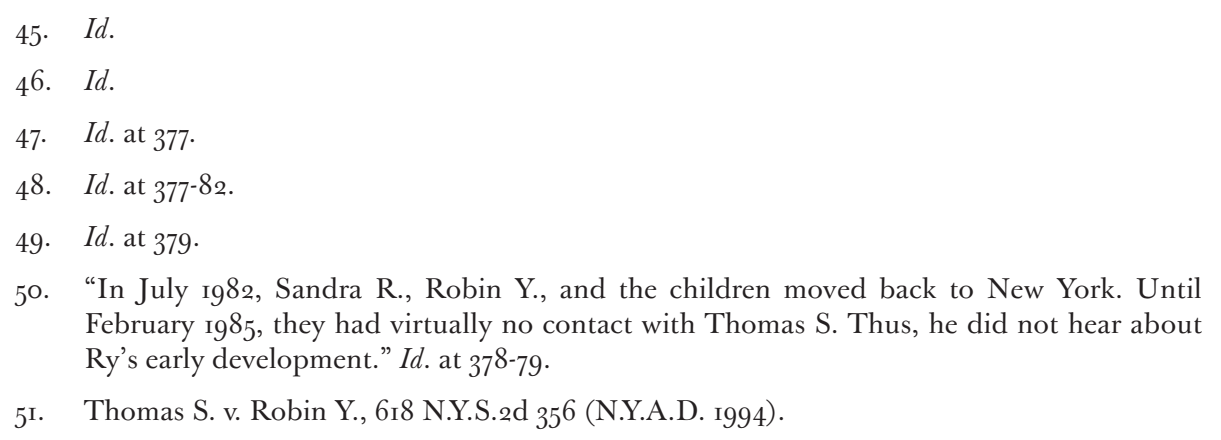


lend themselves to teaching this task, but some may be used to illustrate its importance. One opinion that does this, and allows the instructor to alert students to the role of the lawyer in anticipating the course of the litigation and creating a strategic advantage for his client, is Davis v. Monroe County Board of Education..$^{2}$ A five-justice majority of the U.S. Supreme Court announced that school districts could be liable for student-on-student harassment, under federal law, if the harassment were "so severe, pervasive, and objectively offensive" that it prevented the victim from taking advantage of access to the local school system. 53 As part of the claim, a plaintiff would also have to prove that the school officials knew of the harassment and failed to address the problem, instead showing "deliberate indifference to known acts" of harassment. 54

Because the lower court had decided the case on a motion to dismiss under F.R.C.P. I2(b)(6), the court noted that it would accept the facts pleaded in the complaint as true, for purposes of the motion. 55 Plaintiff's lawyer wisely wrote much more than a bare-bones pleading; the lengthy complaint told a compelling story of harassment, with an array of specific incidents of inschool harassment suffered by a fifth-grade girl at the hands of a particularly obnoxious boy seated next to her in class. $5^{6}$ The plaintiff's complaint recalls the old adage that "if the law is on your side, pound on the law; if the facts are on your side, pound on the facts." ${ }_{77}$ The plaintiff's lawyers pounded on the facts, and the court's five-justice majority responded, making eighteen references to paragraphs of the complaint.$^{8}$ The majority opinion quoted the allegations concerning the boy's vulgar remarks (crediting the fifth-grader with such gems as "I want to get in bed with you" and "I want to feel your boobs"), and described the allegations concerning his offensive conduct (e.g., placing a doorstop in his pants).59 The opinion also detailed the allegations about the school's brazen refusal to do anything to help the victim, despite repeated requests by the girl and by her parents. ${ }^{60}$ Thanks in no small measure to the detailed factual complaint drafted by a lawyer who saw the strategic importance of creating a persuasive document to help his case, the plaintiff's claim narrowly survived a motion to dismiss. ${ }^{6 r}$

52. 526 U.S. 629 (1999).

53. Id. at 630 .

54. Id. at 633 .

55. Id.

56. Id. at $633-36$.

57. In the version I heard long ago, the adage concluded, "If neither the facts nor the law are on your side, pound on the table." American Folklore: An Encyclopedia 9o8-og (Jan Harold Brunvand ed. 1996).

58. Davis, $5^{2} 6$ U.S. at $633^{-3} 6$.

59. Id. at $633-34$.

6o. Id. at 635 .

6I. Id. at 653-54. 
The Court's reliance on the lawyer's complaint in Davis contrasts sharply with the Oregon Supreme Court's treatment of the complaints in Burnette v. Wahl, where three cases alleging child neglect were consolidated for appeal. ${ }^{62}$ The plaintiff children sought damages for the emotional harm inflicted by their mothers, who were alleged to have deserted and neglected them. ${ }^{63}$ This was a claim of first impression, and plaintiffs' counsel could certainly anticipate a motion to dismiss based upon the failure to state a claim. ${ }^{64}$ The complaints were described by the court as "substantially identical" and contained general statements that the mothers had "neglected the plaintiff by negligently leaving ... unattended in or at a place for such period of time as would have been likely to endanger the health or welfare of the plaintiff, in violation of ORS I6 $3.545 . "{ }^{\circ}$ The lawyer for the children had drafted pleadings that were virtually fact-free, instead of providing facts that might have made judges feel the pain and suffering of these particular children ${ }^{66}$ The children lost their case. ${ }^{67}$ The judges, unconstrained by facts, wrote: "There are probably as many children who have been damaged in some manner by their parents' failure to meet completely their physical, emotional, and psychological needs as there are people." ${ }^{68}$ The lawyer for the children failed to make their mental suffering come to life, missing the opportunity to draw unique, compelling portraits of each child's individual life tragedy.

Some cases illustrate how differently majority and dissenting opinions depict the story of the case. In Santosky v. Kramer, the Supreme Court had to determine the proper standard of proof for cases seeking to terminate parental rights. ${ }^{69}$ The parents in the case had mistreated their children in a number of ways that were, to say the least, shocking. ${ }^{7 \circ} \mathrm{A}$ majority opinion favoring the defendant parents rejected the usual standard in civil cases of proof by a preponderance of the evidence, and required the state to prove its case by clear and convincing evidence..$^{7^{1}}$ The opinion characterized the parents' misdeeds as

62. 588 P.2d IIO5 (Or. I978).

63. Id. at 1 IIO7.

64. Id. at mo8 ("Preliminary to a more detailed discussion, it should benoted that these claims of parental failure are different from those tort claims usually made upon behalf of children against parents. The adjudicated cases concern physical or emotional injuries resulting from physical acts inflicted upon children such as beatings and rapes and from automobile accidents. Plaintiffs admit they can cite no cases permitting them to recover from their parents for solely emotional or psychological damage resulting from failure to support, nurture and care for them.").

65. Id. at 1107 .

66. Id. at IIO7-08.

67. Id. at III2.

68. Id. at IIII.

69. 455 U.S. 745 (1982).

70. Id. at 78 r n.ro (Rehnquist, J., dissenting).

7I. Id. at $767-7 \mathrm{I}$. 
simply "incidents reflecting parental neglect." ${ }^{2}$ This minimizing phrase served to downplay the parents' severe parenting deficits. The opinion took advantage of the definition of "neglect" (which could include infliction of serious physical harm) in the state statute to avoid the more common understanding of what the parents did, that is, commit child abuse. ${ }^{73}$ The dissent, advocating less procedural protection for the parents, described the particulars in more direct and graphic terms that depicted serious injuries, fractured bones, cuts on the foot, blisters on the hands, bruises on the arms, forehead and spine, and multiple pinpricks on the back. ${ }^{74}$ Students readily grasp the idea that such a gruesome factual account makes the case for giving the parents enhanced due process rights much less appealing.

\section{Persuasive Advocacy}

What convinces an audience? What distinguishes a persuasive argument from what Abraham Lincoln once called "strings of words meant to pass for arguments"? 75 In the practice of law, one must take a position, defend it, and enlist others in its support. How should the argument be structured, phrased, pitched? What are its elements, how strong is each one, where are the vulnerabilities and how can they be managed? For every case, in every field of law, there is the work of advocacy to be done, fashioning the argument in its best possible dress.

Judicial opinions themselves are examples of persuasive efforts, since judges write in part to convince their readers that the decision being rendered is the best one to be made according to the law. In a doctrinal course it is certainly possible to point out some basic tactics of persuasion in court opinions, and some ideas for doing so are suggested here.

\section{Narrowing the Claim}

Judicial opinions may describe the legal claim made by the plaintiff as if there were only one way to frame the relevant claim. This hides from the student's view the important work of the lawyer in framing a claim, and the choices lawyers have in stating a claim (and sometimes, the choices judges make in characterizing the claim so as to make their judgments seem correct).

One way for a lawyer to lose a potentially winnable case is to overstate the claim, making the case vulnerable to arguments that would not be relevant to a more narrowly stated claim. An example is a New York case, Morone v. Morone, in which a nonmarital co-habitant sought property division and support upon breakup of the relationship ("palimony"). $7^{6}$ Four years before the case, in the

72. Id. at $75^{\mathrm{O}}$.

73. See N.Y. Fam. Cт. Aст § iоI2(f) (20I5).

74. Santosky, 455 U.S. at 78 I n.ro (Rehnquist, J., dissenting).

75. Abraham Lincoln, Speech to the One Hundred Fortieth Indiana Regiment (March 17 , I865), in 8 COLlected Works 36o-62 (Roy P. Basler ed. i953).

76. 50 N.Y.2d $48 \mathrm{I}(\mathrm{I} 980)$. 
celebrated opinion in Marvin v. Marvin, the California Supreme Court had held that all co-habitants in the state could make such claims, as a matter of implied contract, express contract, or equity between the parties.77 The New York Court of Appeals had previously recognized express contracts between co-habitants as valid, but had not approved the use of any other theories of recovery. ${ }^{78}$ The lawyer for the plaintiff in the case, a woman named Frances Morone (she used the last name of her co-habitant, Frank Morone), simply asked the court to adopt the Marvin rule for the state of New York..$^{79}$ Her lawyer failed to win recognition for claims based on anything other than an express contract. ${ }^{80}$ The Court of Appeals had multiple objections to the broad recognition of all cohabitation claims, including concerns about fraud by the claiming party and difficulty in obtaining reliable evidence about the intentions and expectations of co-habitants. ${ }^{8 \mathrm{r}}$

Students may be asked how the claim of Ms. Morone could have been framed in a much more narrow way to allay the concerns that a smart lawyer should anticipate the claim might raise. Instead of seeking recognition for all co-habitants, plaintiff's lawyer could have narrowed the claim to cover only those long-term co-habitants whose intentions and reasonable expectations were clear. The Morones had lived together for 23 years, and raised two children in that time..$^{{ }_{2}}$ The intention to share their lives was not speculative, or subject to fabrication; they had already lived a major portion of their lives together and demonstrated their intention to create a family together. Broadly claiming a right for all co-habitants meant including in the legal claim shortterm partners living together without serious commitments to each other, and youthful partners experimenting with co-habitation, perhaps intending merely to see if they were suited for a possible marriage together. These tentative cohabitation relationships, with their varying degrees of commitment to a shared future, would inevitably cause a court that was more conservative than the Marvin court to hesitate. Marvin involved adult co-habitants with no children who lived together for a relatively short term. ${ }^{83}$ The facts in the Morone case were much stronger, and the woman's lawyer could have framed the claim in a much narrower and more favorable way for his client.

A case that may reflect some law students' high school experience is Brown v. Hot, Sexy and Safer Productions Inc. ${ }^{84}$ In this case, a public high school brought a

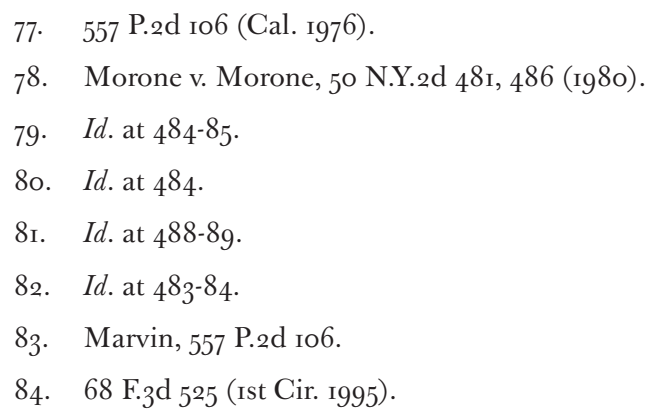


group onto campus to speak to students about AIDS prevention..$^{8_{5}}$ The group, according the complaint filed by two i5-year-old students and their parents, spoke about sex in very explicit and casual terms:

Plaintiffs allege that [instructor] Landolphi gave sexually explicit monologues and participated in sexually suggestive skits with several minors chosen from the audience. Specifically, the complaint alleges that Landolphi: I) told the students that they were going to have a "group sexual experience, with audience participation"; 2) used profane, lewd, and lascivious language to describe body parts and excretory functions; 3) advocated and approved oral sex, masturbation, homosexual sexual activity, and condom use during promiscuous premarital sex; 4) simulated masturbation; 5) characterized the loose pants worn by one minor as "erection wear"; 6) referred to being in "deep sh-" after anal sex; 7) had a male minor lick an oversized condom with her, after which she had a female minor pull it over the male minor's entire head and blow it up; 8) encouraged a male minor to display his "orgasm face" with her for the camera; 9) informed a male minor that he was not having enough orgasms; ro) closely inspected a minor and told him he had a "nice butt"; and II) made eighteen references to orgasms, six references to male genitals, and eight references to female genitals. ${ }^{86}$

The parents' claim, according to the U.S. Court of Appeals for the First Circuit, was that defendants "violated their privacy right to direct the upbringing of their children and educate them in accord with their own views." ${ }_{7}$ The court inveighed against any asserted constitutional right that would result in parents of public school students "prescribing what the state shall teach their children." 88 Supreme Court precedents, the court declared, did not "encompass a broad-based right to restrict the flow of information in the public schools." 89

Students find that narrowing down the claim is tricky. The plaintiffs needed to avoid the appearance that they were trying to dictate the curriculum or limit topics like AIDS prevention that the school might choose to cover. Perhaps the better approach would be to shift the claim's focus from the general topic of AIDS education to the specific values communicated by this particular program-a program that arguably did not merely convey information about sex and AIDS, but condoned and encouraged sexual activity, and even sexual promiscuity, by minors. This restructured claim might have improved the parents' chances of success, though we don't know how the court would have responded to such a claim. But students see how knowing legal doctrine (about public school curricula and parental rights) helps lawyers to plan a legal strategy and put their clients in the best litigation position they can.

85. Id. at 529 .

86. $I d$.

87. Id. at $53^{2}$.

88. Id. at 534 .

89. Id. 


\section{Naming and Labeling the Parties}

Judicial opinions always identify the parties to the proceeding. This routine act masks a key question for an advocate, i.e., how to name the parties in the case. A common choice is first to identify the parties by their full names, and then use only their last names. Another choice is to use the terms "plaintiff" and "defendant." These choices are so habitual that students may not appreciate the other options available to advocates, who are the first ones in the case to choose names and labels for the parties. Some judicial opinions may help show students various strategic choices.

A striking example of labeling of a party occurred in a Pennsylvania case, Ferguson v. McKiernan. $9^{\circ} \mathrm{A}$ woman who had separated from her husband began an affair with another man. ${ }^{9 t}$ When the affair ended, they remained friends, and at some point she asked him to be a sperm donor for her, promising that she would be solely responsible for the child and he would have no financial or other obligations..$^{22}$ She misled the IVF physician into believing that she intended to have the child with her husband and that her husband was the sperm provider. ${ }^{93}$ She gave birth to twins and identified her husband as the father on the birth certificate (she was divorced from him at the time). ${ }^{94}$ Five years later, she sued her friend for child support. ${ }^{95}$

The Court of Common Pleas found that the woman told conflicting stories to her doctor, her husband, and her friend..$^{6}$ The judge concluded that plaintiff's "fraud, deceit, lies and misrepresentations lulled this sperm donor into paternity." ${ }^{97}$ Nevertheless, the judge found the donor was the twins' legal father and under state law he was liable for child support..$^{8}$

In the trial judge's opinion, the donor was called "the defendant." 99 On appeal to the Pennsylvania Superior Court, he became "the appellant." But on further appeal to the Supreme Court of Pennsylvania he was referred to not by his name, or his litigation status as defendant or appellant, but by his role in the procreative act-throughout the opinion, he was called "Sperm Donor." "or This appellation helped the reluctant father by defining him by his

9o. 940 A.2d I236 (Pa. 2007).

9I. Id. at $\mathrm{I} 239$.

92. $I d$.

93. Id. at $1239-40$.

94. Id. at I240.

95. Id. at 1238 .

96. Ferguson v. McKiernan, 6o Pa. D. \& C. $4^{\text {th }} 353$, 36o (Ct. Com. Pl. 2002).

97. Id. at 355 n.I.

98. Id. at $363-64$.

99. Id. at 354 .

IOo. Ferguson v. McKiernan, 855 A.2d I2I, I22 (Pa. Super. Ct. 2004).

IOI. Ferguson v. McKiernan, 940 A.2d I236, I238 (Pa. 2007). 
intentionally limited act in the procreation of the twins. The state supreme court acknowledged his limited role and relieved Mr. Sperm Donor of any child support liability. ${ }^{102}$

Another example is provided by Dunphy v. Gregor, the case discussed previously in which plaintiff Eileen Dunphy sued for damages for emotional distress when she witnessed a negligent driver kill her fiancé Michael Burwell while he was changing a tire on the side of the road. ${ }^{103}$ The state supreme court had previously allowed such a claim to be made by a mother who witnessed the death of her child, but Dunphy sought to extend such "bystander liability" beyond the orbit of traditional family members. ${ }^{104}$ The case presents an opportunity to study the functioning of a common law court in deciding whether to extend an existing doctrine to a new set of facts. It also offers the chance to briefly highlight an important point about identifying parties.

In the intermediate appellate court, the judges described Ms. Dunphy as "plaintiff" and James Gregor as "defendant." "Michael Burwell" and then simply "Burwell." "о6 In the New Jersey Supreme Court opinion, plaintiff is identified as "Eileen" and her fiancé is "Michael." The use of first names for the couple personalizes their story, implies they are young, and helps create goodwill toward the innocent young woman so grievously harmed by the roadside killing. The alleged tortfeasor is simply, and coldly, called "defendant, James Gregor." by his role as the accused wrongdoer in the litigation, and certainly creates no sympathy for him.

These cases show some of the possibilities of using naming and labeling to support one's case. In other fields of law, different options may exist. The defendant in a case involving a dispute over repairs to an apartment, for example, might be identified by plaintiff's attorney as simply "the Landlord." A corporate entity in a business dispute may be labeled "the Corporation." These titles don't generate much warmth or positive regard in our society. In a jury trial, jurors might be expected to identify more with tenants and consumers than with Landlords, Corporations, Directors, Banks, Employers, or others that bring to mind bureaucratic, large, wealthy, impersonal entities.

A criminal law case in Tennessee makes the point in an amusing way. The prosecution sought to have the court order that its client not be referred to as the "government," perhaps out of concern for anti-government sentiment

I02. Id.

Io3. Dunphy v. Gregor, 642 A.2d 372 (N.J. 1994).

I04. Id. at 373 .

I05. Dunphy v. Gregor, 617 A.2d I248, I250 (N.J. Super. A.D. 1992).

Io6. Id.

I07. Dunphy v. Gregor, 642 A.2d 372, 373 (N.J. 1994).

108. Id. 
in a conservative venue. ${ }^{109}$ The defense lawyer vigorously opposed the ban, responding not only with legal argument but with pointed counter-suggestions for renaming both his client and himself. possibility the label "the Citizen Accused," noting that the term "defendant" had unfortunate connotations of guilt." Instead of "the defense" he proposed the term "the Resistance." "12 Defense counsel himself would then be "the Leader of the Resistance." "п3 The court, no doubt with a smile, denied the prosecutor's motion. ${ }^{114}$

\section{Counseling}

While cases don't directly teach about lawyer-client counseling, professors may generate valuable discussions about this aspect of the job of lawyers using traditional case materials. ${ }^{15}$

Consider, for example, the notorious child custody case pitting film director Woody Allen against his ex-companion, actress Mia Farrow. ${ }^{\mathrm{II} 6}$ At stake was custody of three children, two adopted by the couple and one their natural child. ${ }^{ㄲ}$ The trial judge, in awarding custody of the children to Ms. Farrow, took Woody to task for his woefully inadequate knowledge about the children. ${ }^{\text {II8 }} \mathrm{He}$ did not know the names of the children's friends, teachers, pets, pediatrician, or dentist."19 One of the three children had a history of

Io9. Joe Patrice, This Is How You Shame Prosecutors For Their Stupid Motion, Aвоve THE LAW (Oct. 3I, 20I3, IO:I6 AM), http://abovethelaw.com/20I3/IO/ this-is-how-you-shame-prosecutors-for-their-stupid-motion/.

IIO. Id.

III. Id.

II2. $I d$.

II3. Id.

II4. Debra Cassens Weiss, Call me Captain fustice: Laweyer Requests Euphemisms After Prosector Seeks Ban on 'Government' Word, A.B.A.J. (Nov. 4, 2013, II:IO AM), http://www.abajournal.com/news/ article/call_me_captain_justice_lawyer_requests_euphemisms.

II5. Counseling can also appear in lawyer-prepared documents, as impressively demonstrated by one practitioner who created a letter to a client and a settlement document that were designed to help her clients care well for their children and avoid future custody litigation. Patricia Riesenburger, Remembering the Children in a Dissolution Proceeding, FLA. B.J., March r99o at 33. The documents advised clients about what parental behaviors would benefit their children and be viewed favorably by the court should disputes over custody or visitation rights arise in the future. $I d$. at 33-34. The advice is consistent with judicial opinions describing the kind of parental conduct that caused parents in such disputes to lose credibility in the eyes of the judge.

II6. Allen v. Farrow, No. 68738/92 (N.Y. Sup. Ct. June 7, I993), available at http://www.scribd. com/doc/20540362I/Allen-v-Farrow-Custody-Ruling-June-7-I993.

II7. Id. at I.

II8. Id. at $15-33$.

II9. Id. at 16 . 
cerebral palsy, but Woody did not even know if the boy had a doctor. ${ }^{120} \mathrm{He}$ rarely communicated with most of their brothers and sisters (other children of Mia's). ${ }^{121}$ Compounding his litigation problems was the fact that Woody was sleeping with one of the sisters, Mia's child adopted from Korea, Soon-Yi. ${ }^{122}$

Not surprisingly, things did not go well for Woody Allen at trial. None of Woody's own witnesses would give their opinion that he should be granted custody. ${ }^{123}$ Woody's testimony in response to his own lawyer's question ("Can you tell the court why you are seeking custody of your children?") was described by the judge as "a rambling non sequitur which consumed eleven pages of transcript." ${ }^{24}$ Part of his answer pledged that the children's "day-today behavior will be done in consultation with their therapists." ${ }_{225}$ In sum, Woody Allen came across as the archetypal uninvolved parent, unfamiliar with the basic daily lives of his children and insensitive to their feelings about the affair with their sister and the public attacks on their mother's character and parenting abilities. The judge condemned this father's "self-absorption, his lack of judgment and his commitment to the continuation of his divisive assault, thereby impeding the healing of the injuries that he has already caused ...." ${ }^{126}$

A case like this, where a client proposes a perhaps strongly felt but poorly conceived course of action, can set the stage for an exploration in class of a delicate task for a lawyer, counseling against the client's desired action. In this case, we have no information about the lawyer-client conversations, but students can speculate about possible options for the lawyer. A lawyer might offer legal reasons the planned action won't succeed, and might in fact set the judge against the client. Beyond the legal consequences, what of the effects on the client's relationships, his reputation, and his pocketbook? Woody Allen faced more than the loss of his case. The litigation itself, and the way he prosecuted it, might damage what he was presumably most concerned about, his ability to serve in the role of father to his three children. And he had other interests at stake as well. Because of his celebrity, the case was bound to draw mass media attention, negatively affecting his own reputation with members of the general public who pay to see his films. Finally, fully litigating any lawsuit carries enormous financial costs (though someone as rich as Woody

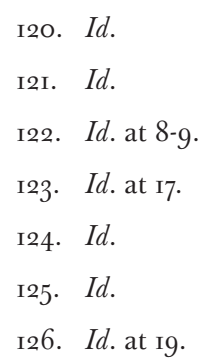


Allen might be willing to absorb them) ${ }^{127}$ All of these "talking points" might be used to counsel a client not to pursue an unwise course of action. ${ }^{128}$

Another case, Matter of Baby Girl W., raises a ticklish question of counseling and legal ethics. ${ }^{129} \mathrm{~A}$ couple seeking to adopt a child were caught misrepresenting their finances, educational attainments, and employment histories. They failed to exhibit any remorse for their false statements. ${ }^{30}$ Students might be asked to imagine the lawyer-client discussion before the couple give their testimony. Can the lawyer advise the clients to show remorse, by directly suggesting it? This would seem to be suborning perjury. What about informing the clients that courts are more lenient with those who show remorse, without directly counseling such testimony? Or telling them about a prior case in which the court was impressed with the show of remorse expressed by an adoptive parent who lied about her background because of her desperate desire to love and

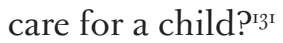

\section{Dealing with Experts}

Cases often feature expert testimony, and lawyers must learn to understand the uses and limits of expertise. In family law, the expertise offered is often in psychology, and students without a background in the subject may think the lawyer's role is simply to call upon experts when needed and accept all they say. I try to use the cases to instill a more nuanced and critical view, while respecting the importance and value of well-founded expert testimony.

A judicial opinion that relies significantly on such testimony can be a good vehicle for raising a number of issues about how lawyers deal with experts. One example is a fascinating old case in family law, Painter $v$. Bannister. ${ }^{132}$ Harold Painter was the father of a 5-year-old boy, Mark. ${ }^{33}$ Tragedy struck when Painter's wife and daughter were killed in an automobile crash. ${ }^{34}$ Painter asked

I27. In fact, Allen was ordered to pay Farrow's counsel fees as well, in part because of the "relative lack of merit of Mr. Allen's position in commencing this proceeding for custody." Allen v. Farrow, 197 A.D.2d 327, 335 (N.Y. 1994).

I28. Attorney Margaret Klaw, in her book about her cases as a family lawyer, amusingly describes things she's talked clients out of, including submitting evidence that a mother buys clothes for the child at a thrift store, that the mother is a lesbian, that the father is an atheist, and that the father's new girlfriend paints his daughter's fingernails. MARGaret KLAW, KeEPing IT Civil 216-I7 (20I3).

I29. 542 N.Y.S.2d 415 (N.Y. App. Div. 1989).

I3०. Id. at $4 \mathrm{r} 6$.

I3I. The couple in the case were able to adopt the child, because the majority felt that the most important evidence in the case was their proven ability to care for the child, who had been living with them for some time. Id. But the lying and lack of remorse led one judge to dissent. Id. at $4 \mathrm{I} 6-\mathrm{I} 7$.

I32. I40 N.W.2d $5_{52}$ (Iowa I966). Professors may also want to read the plaintiff's fascinating account of the case written a year after the decision. Hal Painter, MARK, I Love You (1967).

I33. I40 N.W.2d at 153 .

I34. Id. 
his wife's parents, the Bannisters, to take Mark to live with them temporarily, in their Iowa home. ${ }^{3} 35$ They did so, but when Harold asked for the boy's return two years later, the Bannisters refused to give Mark back to his father. ${ }^{1{ }^{6}}$ The resulting custody battle went all the way to the Iowa Supreme Court. ${ }^{137}$ The court awarded custody to the Bannisters, stating it was much impressed by the testimony of Dr. Glenn R. Hawks, the eminent head of the department of child development at Iowa State University, whose testimony strongly favored the Bannisters. ${ }^{13}{ }^{8}$

The opinion recites that Hawks "spent approximately 25 hours acquiring information about Mark and the Bannisters, including appropriate testing of and 'depth interviews' with Mark." 39 Hawks concluded that Mark used Mr. Bannister as a father figure and was "confused" about the father figure in his life before Mr. Bannister. ${ }^{140}$ The expert voiced grave doubts about how well Mr. Painter could relate to Mark, "because he has got to build the relationship from scratch. There is essentially nothing on which to build at the present time. Mark is aware that Mr. Painter is his father, but he is not very clear about what this means." ${ }^{141}$ Hawks predicted that Mark would do poorly if returned to his father based upon adoption studies that purportedly showed that "the majority of adoptions in children who are changed, from ages six to eight, will go bad if they have had a prior history of instability, some history of prior movement." ${ }^{142}$

I ask students to assume they represent Harold Painter. Dr. Hawks poses a substantial threat to their client's case and to his relationship to his own son for many years to come. What might be the bases for challenging the testimony of Dr. Hawks? By phrasing the issue for discussion this way, the instructor signals students that they do not need to judge whether Hawks is right or wrong; they only must think about how his opinion may be subject to interrogation.

Even without expertise, students can draw upon the intelligent use of common sense to identify several avenues to pursue in mounting a challenge to this expert. If a custody decision is a choice between alternative custodians, did Hawks have sufficient information with which to make this choice? What is missing, of course, is information about Mr. Painter, whom Dr. Hawks left out of his investigation. The expert drew conclusions about the father-son relationship without talking to the father or seeing the father and son interact

I35. Id.

I36. Id.

I37. Id.

I38. Id. at $\mathrm{I}_{5} 6-58$.

I39. Id. at I57.

I4O. Id.

I4I. $I d$.

I42. Id. at $157-58$. 
with each other ${ }^{143}$-is that a proper inquiry? The expert did interview Mark ${ }^{144-}$ but are there reasons, other than the absence of any meaningful parental relationship, that Mark might appear to be confused when talking about his father to a psychologist? Is there a possible alternative explanation to the one offered by the expert, that the boy is confused about the relationship because there's "nothing" to it anymore? ${ }^{145}$ The expert found Mr. Bannister to be a father figure ${ }^{146}$-does that necessarily mean Painter has been supplanted and is now of little importance to his son? And what of the reliance on adoption studies? ${ }^{\text {P47 }}$ Is there a dependable analogy to be drawn from an adoption situation to a case in which a 7 -year-old son is returning to a father with whom he lived for his first five years of life? In a guided class discussion, students can see how the lawyer for Painter can question (i) the expert's inadequate inquiry, (ii) the expert's dubious explanations, and (iii) the expert's deficient analogy. ${ }^{148}$

The distinguished jurist Charles Breitel, a former chief judge on the New York Court of Appeals, put the matter well when he wrote: "In custody matters parties and courts may be very dependent on the auxiliary services of psychiatrists, psychologists, and trained social workers. This is good. But it may be an evil when the dependence is too obsequious or routine or the experts too casual." ${ }^{49}$

\section{Conclusion}

In traditional doctrinal courses in law school, coverage is broad and time is short. Basic courses, like my own in family law, cover a multitude of topics, and in addition to teaching doctrine, they impart important skills such as case analysis and case synthesis. Judicial opinions are the backbone of these courses.

Despite the pressures of time, there is a way to incorporate discussion of other skills of the lawyer into these courses. I here suggest that in a modest but meaningful way, professors teaching doctrinal courses might inject into class

I43. Id. at I57 ("[Dr. Hawks] is criticized for reaching this conclusion without investigating the Painter home or finding out more about Mr. Painter's character.").

I44. Id. at $\mathrm{I} 57$.

I45. Id.

I46. Id.

I47. Id. at $\mathrm{I} 57^{-5} 5^{8}$.

I48. For other bases for challenging experts, see Thomas R. Litwak et al., The Proper Role of Psychology in Child Custody Disputes, I8 J. FAm. L. 269 (1979-80); Stephen A. Newman, Assessing the Quality of Expert Testimony in Cases Involving Children, 22 J. Psychiatry \& L. I8I (I994); Stephen A. Newman, The Use and Abuse of Social Science in the Same-Sex Marriage Debate, 49 N.Y.L. Sch. L. Rev. 537 (2004). A case with an astonishingly thorough custody evaluation by a team of experts, including a memorable anecdote favoring one of the parties, is McLaughlin v. Pernsley, 693 F. Supp. $3^{\mathrm{I} 8}$ (E.D. Pa. I988), affd, 876 F.2d 308 (3d Cir. I989).

I49. Bennett v. Jeffreys, 40 N.Y.2d 543 (I976). 
discussions matters such as the role of the lawyer in gathering evidence, using narrative techniques in presenting evidence, stating legal claims, naming and labeling parties, counseling clients, and dealing with experts.

A modest degree of discussion along the lines outlined in this essay might help show students the vital connections between reading judicial opinions in an academically rigorous manner, and practicing law in a creative, persuasive, and artful way. 